\title{
Arguments in a Sartorial Mode, or The Asymmetries of History and Philosophy of Science
}

\author{
Robert J. Richards
}

The University of Chicago

The assumption underlying this symposium betrays an unusual transformation of attitude and an uncharacteristic openmindedness, in that it holds that philosophers of science can learn something from historians of science. Philosophers of science used to regard historians as rather dull witted. But attitudes have changed, and for fair reason. A judicious assessment of the two disciplines in the last decade or so would suggest that many of the interesting philosophical questions have flowed from history. As I will argue in a moment, this is exactly what one should expect. We might well ask, of course, whether historians can learn something from philosophers of science. To answer either of these questions requires, first, a consideration of the asymmetrical relations between the two. In toting up these asymmetries, I will sometimes count scientists who write on their own history with philosophers of science, since their sins are common.

A glaring asymmetry, obvious at this meeting, is that historians dress better than philosophers-historians always being interested in the details, sartorial and otherwise, while philosophers seem concerned only with dressing in general. Beneath what may seem a rather superficial difference, though, lies their principal and divergent intellectual trajectories. Historians spend their time worrying about the details: the dates, the places, the specific contexts of ideas, discoveries, experiments, and claims. For philosophers, on the other hand, it's the generalizable character of the events; they rip ideas, discoveries, and experiments untimely out of context so as to generalize from them, to make them representative of a larger class, to assess the merits of their claims in terms of more abstract norms, and to trace out their implications. Of course, the historian does occasionally lift an eye toward the universal, just as the philosopher will stumble across this or that nasty little fact.

Another asymmetry concerns the kind of training of each. Historians, aside from learning the general go of the history of science, or at least of the particular science or period in which they will do research, spend no little time acquiring special skills, paleography and languages in particular, or perhaps an antiquated mathematics. Historians do this in order to understand the science and the age in context. Historians as well attempt to trace back published works to their origins in the notebooks kept, the letters written, and the books read; and languages are necessary for this. Philosophers, aside from reading the classics in their areas of concern and the secondary literature, do

PSA 1992, Volume 2, pp. 482-489

Copyright (C) 1993 by the Philosophy of Science Association 
worry about their main tool as well. The question, for the philosopher, though, is not "Do I know this language?" but "Am I smart?" The historian of science works with things-letters, notebooks, papers, even ancient experimental apparatus-and tries to make them yield a set of causal conditions that render a particular scientific discovery, formulation, or claim understandable. The philosopher works with abstractions-the nature of theory, observation, hypothesis, explanation - and a clever mind is required to understand those relationships. But therein lies, in the historian's estimation, an invitation to tragedy and possibilities of great sorrow.

In Rome, Edward Gibbon, while he sat musing on the ruins of the Capital, resolved to write his Decline and Fall as he listened to the barefooted friars chanting in what was once the temple of Jupiter (1984, p. 143). Gibbon wept, as many a historian has when contemplating the ruin philosophical mendicants have visited upon the past, precisely because of their devotion to the universal. Not even Virgil could discover that pit beyond the circle of treachery into which historians would cast unregenerate philosophers and scientists for the unpardonable sin, that of presentism: reading present concerns and ideas back into the past. The inclination to generalize for all times and places-say, the nature of theory, or the causes of theory change-easily leads one to believe that the logic of present science was also that of science past. Steve Gould, for the moment an honorary philosopher, persists in interpreting Darwin's theory as rejecting progress. "The summum bonum of Charles Darwin's world is survival and persistence, not progress or improvement," he writes recently (1992, p. $165)$, as he has before (1977, p. 45). Only a steady eye on contemporary neoDarwinism could produce such a universalizing judgment. Needless to say, Darwin was not a neo-Darwinian, a surprisingly controverted thesis, which one recent book has definitively argued, with, I think, complete persuasive effect (Richards, 1992a), and another, which surveys the idea of progress from the nineteenth century to the present, Michael Ruse's current endeavor (forthcoming), will show, if wise, that thesis to be not only an acceptable analytic proposition but one historically supportable.

Beneath the asymmetry of particularity and universality lies a more subtle one: it concerns the engine that makes the research and writing take off. Two colleagues of mine at the University of Chicago, Leonard Linsky — an analytic philosopher-and William McNei-world historian (in both senses of that phrase)-had, a while ago, a sabbatical during the same year. It happens that they live next to one another in Hyde Park. In the late spring, McNeil asked Linsky how his work was going. Linsky said during his whole sabbatical he hadn't done a thing. He just couldn't get the ideas to come out. McNeil was nonplusied. He couldn't understand the difficulty. During his year's leave, he had drafted a substantial book. As an historian, you do your research-read primary and secondary literature, go to archives-and then you arrange your notes and sit down and write. The history is out there; you simply must capture it on paper.

Now this, of course, is a bit too simple a view of the historian's task, but it does highlight the difference of subjects and how the traditional practitioners of the two disciplines conceive their goals. The philosopher must create certain ideas, and put them together, which on the surface seems the easier job but often turns out to be rather difficult. The historian, in a certain sense, finds ideas ready made; most of them lie in documents, or are derivable from documents. He or she must, of course, discover them, isolate them, and then reset them in their appropriate context. Even the poor historian will sometimes produce something of interest, usually a description of a hitherto unknown document or, perhaps, a story of an event or set of relationships not before recognized. The poor philosopher, almost by definition, never produces anything of interest; for a poor philosopher's ideas do not mesh; his or her theory becomes swiss cheese as counter-examples are propelled into it. 
The task of the good historian, however, is more difficult than that of even the good philosopher. It's simply harder being a good historian than a good philosopher. There are two principal reasons for this, I believe. First, the philosopher works with constructed ideas, and thus he or she can mold the ideas and establish their connections while worrying, for the most part, only about transgressing the principles of logic; the connection of these ideas with the empirical world is not a primary issue - and, after all, if observations are permeated by theory, then the empirical world becomes rather like silly putty in the hands of a dexterous philosopher. The good philosopher of science tests his or her conceptions, not usually against the given, messy particulars of scientific practice but against the rational reconstruction of that practice, which rational reconstruction tends to be, perhaps not surprisingly, awfully friendly to the concepts being tested. The good historian, by contrast, must be creative in a medium - namely the past with its jagged contours, unforgiving heights, and obscure depths - that allows only the most creative of minds to make something of it anew. The historian would like to tell the story one way, but the material will not support it. The story he or she wishes to tell logically could have happened in the desired way; but the facts run against the grain of the narrative. Like Michelangelo, the historian has to make the David come out of just this piece of Carrara marble. The historian must sculpt with care and ingenuity, for the fracture lines of the medium will reduce to dust many a possible narrative.

The second reason for the difficulty facing the good historian concerns the mode of expression. Historians who will do important work must heed the prayerful verse of Charles Kingsley over his daughter. He said: "Be good, sweet maid, and let who will be clever." The good historian, though, will also be clever, as able and as dexterous with a concept as any philosopher. But the historian must do more to be good. $\mathrm{He}$ or she must capture the past in an arresting narrative, a compelling story that drags the reader in. Boring histories are written by boring historians, generally poor historians. The good historian will not tell a boring tale. He or she will make it come alive using all the techniques known to good novelists and even poets. And history is served by this. Since what will be conveyed by the good historian is not simply a sepia-toned picture of the past, but a living, moving picture-one that does not merely describe emotions and attitudes, but recreates them, engenders them in the reader. An essential task of the historian, I believe, is to recreate the past on the page, so that motivations, feelings, loves, and hates will emotionally move the reader to understand how the actors could make certain decisions and take certain steps. Of course, the historian of science will attempt to display the material logic of a set of ideas that would explain an actor's behavior; but rarely will cold ideas alone provide the steam necessary to motivate an action. David Hume, the great Tudor-Stuart historian, was right when he said reason is and ought to be the slave of the passions. For the historian to unspring those passions on the page, to make the reader feel them, will simultaneously help explain the behavior in question. And that is the most difficult task of the good historian-to make the history come imaginatively alive, to recreate in the minds of the readers the motivational context of past science, but yet to have the historian's imagination constrained by and that recreation held within the bounds of what can be demonstrated, proved, or at least supported by the facts. Thomas Babbington Macaulay, the great nineteenth-century British historian, put it thus:

A perfect historian must possess an imagination sufficiently powerful to make his narrative affecting and picturesque. Yet he must control it so absolutely as to content himself with the materials which he finds, and to refrain from supplying deficiencies by additions of his own. He must be a profound and ingenious reasoner. Yet he must possess sufficient self-command to abstain from casting his facts in the mould of his hypothesis (1828, pp. 1-2). 
Macaulay mentions the source of a chief complaint historians have about philosophers: the use of historical cases as exemplars molded in the form of whatever hypothesis the philosopher is advancing. The cases become factoids used to demonstrate the hypothesis, and they are synthesized into smooth little nuggets just for the purpose.

Now, I don't wish to suggest that historians do not formulate theories and test hypotheses. They do. But the theories and hypotheses are usually of a very low level, and they arise most often out of the research itself. If further research does not support them, then the historian will usually abandon those theories without, however, being required to abandon the particular history he or she is writing. When a philosophical theory is undermined, well the beast should die on the spot. Rarely does that happen, of course. You can never quite tell when a philosophical theory has died; it seems embalmed from the beginning so as to prevent rot. Historical theories act more responsibly. When confronted with lethal evidence, which is most often of a harder, more factual sort, they usually give up the ghost.

Though there are many other asymmetries that characterize the relationships of these disciplines, let me mention perhaps the most important one. And that is: decent history of science can survive without philosophy of science, but philosophy of science, by the logic of its own discipline, absolutely requires the aid of history of science. Historians can take the meaning of theory, hypothesis, observation, explanation, and so on from the historical events themselves-Darwin, for instance, used all of these notions - of theory, hypothesis, etc.-and his efforts exemplified them. Here is the source of their meaning for the historian. He or she need not repair to the philosopher for an authenticated concept to employ. The philosopher of science, on the other hand, will be engaged in arguing for a particular conception, say, of scientific explanation. Ultimately he or she can justify that conception only by appeal to successful explanations in science - that is, of necessity, to some past bit of science to justify his or her position. What is the alternative-metaphysical or epistemological intuition? Certainly one can formulate a priori a model of explanation, but to advance it as the model of scientific explanation, or even explanation in, say, biology, requires the philosopher to justify it against actual examples of explanations that have been used in science - and history is needed for that.

Of course, philosophers of science, especially those writing today, attempt precisely this sort of justification. They most often do test their models by appeal to historical examples. Usually, however, the historical episodes, appropriately sanitized, serve only as examples. Consider, for instance, the efforts of Michael Ghiselin, Michael Ruse, and Philip Kitcher-their efforts to uncover the explanatory structure of Darwin's theory. Ghiselin, in his Triumph of the Darwinian Method (1969, p. 129), discovers that method to be the hypothetical deductive method, as refined by philosophers in the late twentieth century. Michael Ruse - that is, a younger, greener, less historically seasoned Michael Ruse-suggests much the same in his Darwin Revolution (1979). More recently, Philip Kitcher, in a longish article in Minnesota Studies (1989) worked out a theory of explanation in which the systematic unification provided by theory bears the explanatory power. He had written, shortly before, another article (1985), ostensibly more historical in character, on the argument strategy of Darwin's Origin of Species (1859). The historical analysis of that Darwin piece led, not surprisingly, to the conclusion that Darwin had adopted a Kitcherian view of explanation. Since Kitcher's notions about systematic unification are amorphous enough not to impose a heavy theoretical burden on his historical analysis, the damage to the history is not extensive - along the way he actually says some very acute things, things that challenge ordinary readings. Using Kitcher's account, let me mention what I take to be the distinguishing features of a philosopher's approach to histor- 
ical analysis. I could have used Michael Ruse as the example, but, as Justice Holmes remarked, great cases like hard cases make bad law.

Kitcher's analysis requires him to suggest that Darwin's main accomplishment was to advance certain questions about geographical distribution, variation, and unity of type as central questions of biology. Kitcher claims that such questions were, up to Darwin's time, deemed impossible of answer since their resolution could be found only within the bosom of the Deity-they admitted only a vague theological account, and not a scientific one. So that Darwin's main accomplishment, according to Kitcher, was to show that such questions were important scientific questions, and their scientificity was demonstrated by the systematic answers Darwin could advance (1985, pp. 146-47). Kitcher's analysis supposes, but does not historically show, that such questions as geographical distribution, unity of type, and variation had not been given systematic treatment prior to Darwin. But any historian of biology would recognize these and other like questions Darwin handles as central to the concerns of his predecessors; these were questions that had been given several systematically related answers. (Charles Lyell, of course, considered in depth the "laws which regulate the geographical distribution of species" [1832, pp. 66-175], as well as "variability of a species" [1832, pp. 18-65] and unity of type [1832, pp. 62-5].) Moreover, the contrast between theological answers and scientific ones stands as sharply defined today as it was befogged in the mid-nineteenth century. A measure of this lack of separation between what we think of as science and what theology can be discerned in the Origin itself, which proposes a broad theological framework within which to understand the operations of evolution by natural selection. Indeed, it is hard to understand Darwin's conception of natural selection, or the explanatory power it had with many of his readers, without historically contextualizing it and recovering its status as a fundamentally theological concept (see Richards, forthcoming).

More problematic and more representative are Kitcher's assumptions about theoretical explanation and his use of history to confirm those assumptions. Kitcher and other philosophers who have tried to determine the explanatory logic of Darwin's theory, especially as represented in the Origin of Species, have assumed, or I would say, have imposed, on the argument of the Origin, a simple, logically unified, and systematically related structure - the model of which is Hempel's nomological-deductive scheme. The assumption, then, is that the phrase "Darwin's theory" names such a stable, logically tight structure that underlies its various expressions-expressions which evince the structure after a suitable "rational reconstruction." The historian, however, implicitly recognizes theories in science as historical entities whose parts are not bound together by the silver threads of logic, but by baser ties of causal contingency and changing selective forces. The historian will understand Darwin's theory to have continued to evolve from first conception through final edition of the Origin. The various changing parts of the theory will have shifting relations to other parts and the evidence specified. Further the explanatory power will reside as much in the metaphors employed, the background beliefs of the readers, and their familiarity with the evidence (see Richards 1992b). Several of Darwin's readers were compelled by the theological character of natural selection, a powerfully persuasive feature that has gone completely anemic in modern times.

These two ways of regarding theory, the philosopher's and the historian's, mark their general intellectual tendencies - the philosopher scouting after the stable, unchanging, and universal, the historian after the contingent, fleeting, and particular. Ever has it been thus. 
Equally problematic, to return to Kitcher's analysis, is the modus operandi in his use of history, which is typically that of the philosopher of science. As with most philosophical analyses of explanation, Kitcher's model doesn't flow from the historical analysis, but is imposed upon the history; the historical analysis becomes the deductive conclusion from the model. The model itself, in Kitcher's case, is shaped more against the contrary model of Hempel and the objections formulated against the nomological-deductive type of explanation, objections now schooling as numerous as the alewives off the shores of Lake Michigan. The result of Kitcher's Darwinian exercise-and here I let it stand for many similar efforts by philosophers who have made a conscientious attempt to employ extended historical examples-Kitcher's analysis exhibits the burden of philosophy on history, or in Macauley's terms, it reveals too much the casting of facts in the mold of the hypothesis. And this will always be the deep suspicion that historians have about philosophers, till those philosophers themselves become historians.

These objections from the historian's point of view should not be taken to deny the power and interest of Kitcher's analyses, or those of other philosophers, the young Michael Ruse, for instance. Concerning Kitcher's and Ruse's efforts, one might adapt the line Ronald Knox chose for own epitaph: Their sins were scarlet but their books were read.

I've argued that decent history of science can get along quite nicely without the interference of philosophy of science. Certainly most Ph. D. programs in history of science at various universities, here and abroad, confirm that assumption. And in some notable instances, the attempted marriage of history and philosophy of science in the same department has demonstrated the instability of such unions. It is a dreary conclusion from this observation, but amply supported by the evidence, that history of science remains sublimely indifferent, if not hostile, to philosophy of science.

For the historian to practice simply decent history of science can hardly be an exalted goal. Good history of science, which ought to be the goal, cannot often be executed, I think, without the aid of those conceptions honed by philosophers of science. Good history of science will not simply offer penetrating analyses of the context of particular episodes, but it will extend those considerations, generalize them, make an argument about the nature of the episodes or of science during particular periods. The historian can accomplish this only by critically considering such things as, for instance, the nature of explanation or the causes of theory change or theory acceptance. Historians fall into uncritical and debilitating confusion when they utilize unreflectedupon categories, arguing in innocence of the kinds of analyses that philosophers have undertaken. In Leviathan and the Air Pump (1985), for example-now to knock those in the history trade-Shapin and Schaffer would have been more hesitant in advancing an argument that teetered so precariously on the unstable Wittegensteinian concept of "form of life" had they read, say, Donald Davidson's "On the Very Idea of a Conceptual Scheme" (1974). From the philosopher's point of view, they could have spent more time reading Hobbes, as well.

Now having argued the asymmetries between philosophy of science and history of science-in the mode, it will not have escaped your notice, of a philosopher who has dealt more in stereotypes and ideal cases - can my conclusion be anything other than the trite one that philosophers of science must become knowledgeable in the history of science. Well, I'll dare to be trite, and say it's at least that. But I think more has to be demanded of philosophers of science - if they wish to do philosophy in the most complete way. They must be trained in history of science, after the manner of historians. Sometimes philosophers will read assiduously the secondary literature of 
history of science-but this is not enough; it's certainly not the way historians themselves become trained. At other times, philosophers will focus on the primary literature-say the Origin of Species. But this too is insufficient. They must read both secondary literature and primary literature simultaneously. Moreover, they must needs trace sources back to their origins in notebooks, letters, and unpublished papers. In short, they must become credible historians. Such immersion in the history will provide those originating ideas that perhaps can be generalized in striking and exciting ways, in ways some at this session have already accomplished. And my critical remarks are not meant to demean any of those efforts of the several here who alternately pass as philosophers and historians.

If philosophers undertake training of this kind, and, as befits their species, reflect on the new realities, they will come, I think, to the same assumption that guides most historians. It is an assumption historians harbor but would not fain articulate, lest they sound too much like philosophers. This is the general thesis that theories in science are historical entities, not abstract forms dwelling in a Popperian third world. They evolve over time and thus can sustain only short term generalizations. If that is true, then the entangling relationships of theory with explanation, observation, justification, and transformation will also be recognized as historical. Such historicization will, in those of proper disposition, curb the overwrought generalizing tendency that suffuses philosophy of science, and allow its practitioners more easily to heed Macaulay's injunction not to cast one's facts in the mold of a favored hypothesis.

Historians, who wish to be good and ply their trade in more than the conventional ways, must also accommodate themselves to their opposite numbers. They must train in the argument styles and become apprised of the literature in philosophy. Until philosophers become historians or historians philosophers, neither the philosophy of science nor the history of science will be well served.

\section{References}

Darwin, C. (1859), On the Origin of Species. London: Murray.

Davidson, D. (1974), "On the Very Idea of a Conceptual Scheme," in Truth \& Interpretation. Oxford: Oxford University Press, 1984.

Ghiselin, M. (1969), The Triumph of the Darwinian Method. Berkeley: University of California Press.

Gibbon, E. (1984), Memoirs of My Life. London: Penguin.

Gould, S.J. (1977), Ever Since Darwin. New York: Norton.

. (1992), "Heterochrony," in Keywords in Evolutionary Biology, eds. E. F. $\bar{K} \overline{e l l e r}$ and E. Lloyd. Cambridge: Harvard University Press.

Kitcher, P. (1985), “Darwin's Achievement," in Reason and Rationality in Natural Science, ed. N. Rescher. Washington, D.C.: University Press of America.

(1989), "Explanatory Unification and the Causal Structure of the World," in Minnesota Studies in the Philosophy of Science, Vol. 13: 
Scientific Explanation, eds. P. Kitcher and W. Salmon. Minneapolis: University of Minnesota Press.

Lyell, C. (1832), Principles of Geology, vol. 2. London: Maori.

Macaulay, T. (1828), "History," in Miscellaneous Essays and the Lays of Ancient Rome. London: Dent, 1910.

Richards, R.J. (1992a), The Meaning of Evolution: the Morphological Construction and Ideological Reconstruction of Darwin's Theory. Chicago: University of Chicago Press.

_ _ _ _ . (1992b), "The Structure of Narrative Explanation in History and Biology," in History and Evolution, eds. M. Nitecki and D. Nitecki. Albany: State University of New York.

. (forthcoming), "Theological Foundations of Darwin's Theory of Evolution," in Science in Context, eds. K. Parshall and P. Theerman. Rutgers: Rutgers University Press.

Ruse, M. (1979), The Darwinian Revolution. Chicago: University of Chicago Press.

_- _. (forthcoming), Molecules to Man: The Concept of Progress in Evolutionary Biology.

Shapin, S. and Schaffer, S. (1985), Leviathan and the Air Pump Princeton: Princeton University Press. 